Politics in the Semi-Periphery 


\section{Politics in the Semi-Periphery}

\section{Early Parliamentarism and Late Industrialization in the Balkans and Latin America}

Nicos P. Mouzelis 
ISBN 978-0-333-34934-2 ISBN 978-1-349-18019-6 (eBook)

DOI 10.1007/978-1-349-18019-6

(C) Nicos P. Mouzelis 1986

Softcover reprint of the hardcover 1st edition 1986 978-0-333-34933-5

All rights reserved. For information, write:

St. Martin's Press, Inc., 175 Fifth Avenue, New York, NY 10010

Published in the United Kingdom by Macmillan Education Ltd.

First published in the United States of America in 1986

ISBN 978-0-312-62886-4

Library of Congress Cataloging in Publication Data

Mouzelis, Nicos P.

Politics in the semi-periphery.

Bibliography: $p$.

Includes index.

1. Political participation-Balkan Peninsula--History.

2. Political participation-South America-History.

3. Civil-military relations-Balkan Peninsula-History.

4. Civil-military relations-South America-History.

5. Balkan Peninsula-Industries-History. 6. South America-Industries-History. I. Title.

$\begin{array}{llll}\text { JF2011.M68 } & 1985 & 323^{\prime} .042 & 84-27738\end{array}$

ISBN 978-0-312-62886-4 
To the memory of my father 


\section{Contents}

Acknowledgements $\quad$ xi

General Introduction xiii

\section{PART I}

1 Modes of Transition to Post-oligarchic Politics:

The Demise of Oligarchic Parliamentarism in the

Balkans and Southern Latin America 3

Introduction 3

1.1 Socio-economic processes leading to the early $\begin{array}{ll}\text { demise of oligarchic parliamentarism } & 7\end{array}$

1.2 Routes to post-oligarchic politics $\quad 15$

1.2.1 Urban populism 15

$\begin{array}{ll}\text { 1.2.2 Peasant populism } & 29\end{array}$

1.2.3 The transformation of clientelistic networks 39

1.3 Initial stages of industrialisation and the incorporation of the industrial working classes $\quad 50$

1.3.1 Industrialisation 51

1.3.2 The working-class movement in the Balkans 55

1.3.3 The working-class movement in southern Latin America 62

Conclusion

2 Theoretical Implications (1):

Clientelism and Populism as Modes of Political Incorporation

2.1 On the concept of incorporation 73

2.2 Populism and clientalism as modes of political inclusion

2.3 Some basic differences between clientelistic and populistic incorporation

2.4 From clientelistic to populistic in politics 83

2.5 The debate on the nature of populism $\quad 88$ 


\section{PART II}

3 Routes to Military Dictatorship:

A Comparative Essay on Argentina, Chile and Greece 97

3.1 The military in the early post-oligarchic era 97

3.1.1 The military's role during the transition 99

3.1.2 Variations in civil-military relations: the conservatives' post-oligarchic electoral strength and army dominance

3.2 The post-war expansion of industrial capitalism: restricted and uneven development

3.3 On the basic political structures of Argentina, Chile and Greece

3.3.1 The limiting framework 122

3.3.2 Vertical incorporative modes of inclusion $\quad 126$

3.3.3 The major political contradiction 129

3.4 On the post-war rise of military dictatorial regimes 134

3.4.1 Greece 134

3.4.2 Argentina 145

3.4.3 Chile 158

3.4.4 Conclusion $\quad 170$

3.5 Postscript: a short note on the structure and dynamics of the post-war military dictatorships in Argentina, Chile and Greece

4 Theoretical Implications (2):

Praetorianism, Bureaucratic Authoritarianism, and Problems of Reductionism in Marxist Political Theory

4.1 Military interventions and theories of political modernisation

4.2 The rise of bureaucratic-authoritarian regimes: notes on the relevant literature

4.3 On the relationship between the economic and the political: problems of reductionism in Marxist political theory

4.4 Relations of production and relations of domination: the relevance of the distinction for the study of political development in the semi-periphery 
Contents ix

General Conclusion $\quad 219$

Notes and References 224

$\begin{array}{ll}\text { Index } & 270\end{array}$ 


\section{Acknowledgements}

I would like to thank the foilowing persons who, at one time or another, have read parts of this work and offered me comments that proved very useful: Omar Bayoumi, Rodi Calderón, George Catiphores, Percy Cohen, Nikiphoros Diamandouros, Nicos Garganas, Mike Gowan, John Hall, Vasilis Kapetanyiannis, Cristobal Kay, Christos Lyrintzis, Shelia Massoliver, David Rock, David Rosenberg, Ian Roxborough, Philip Schmitter, Leslie Sklair, Anthony Smith, Constantine Vaitsos, Thanos Veremis, and Costas Vergopoulos.

My particular thanks go to Gustavo d'Angelo and Luis Ortega as well as to José Muñoz, José-Miguel Albala and Ximena Nascimento for their constructive advice and help with Spanish texts.

Very much gratitude is due also to George Dertilis and Mick Mann for very carefully going over the entire manuscript and giving me both useful advice and moral support.

My warm thanks go to Ellen Sutton for her excellent language editing and for preparing a bibliography which, for reasons of space, had to be dropped.

I would finally like to express my gratitude and love to Claire Baron for her constant moral and practical support. 


\section{General Introduction}

While it may be conceded that there are systematic differences between western European capitalist development on the one hand, and on the other the development or underdevelopment of all those countries that have tried to 'catch up' with the West a century or more later, there is nevertheless such a complexity and enormous variety of political and economic systems in the socalled third world that any attempt to discuss the nature and structure of the state and politics in these societies without differentiating between them is bound to fail. It can only result in generalisations which are either platitudinous or inconclusively vague.

In view of these difficulties the present work attempts to go beyond the third-world blanket approach, by focussing on a limited number of societies that have certain crucial features in common with respect to the timing of their political independence, their adoption of parliamentary institutions, and their development of industrial capitalism.

Despite the geographical distance and the obvious differences in cultural and historical backgrounds, Greece and (to a lesser extent) the major northern Balkan societies before their post-war collectivisation ${ }^{1}$ show marked and significant similarities with the 'advanced' countries of Latin America's southern cone. ${ }^{2}$ Until the beginning of the nineteenth century, Balkan as well as Latin American societies were subjugated parts of huge patrimonial empires (the Ottoman and the Iberian respectively), and as such never experienced the absolutist past of western and southern European societies. ${ }^{3}$ Moreover, both the Balkan and southern Latin American countries acquired their political independence in the nineteenth century and immediately set about implementing western parliamentary forms of political rule. Notwithstanding the 
constant malfunctioning and fragility of such forms, their parliamentary institutions evinced a surprising degree of resilience, surviving and functioning more or less intermittently from the second half of the nineteenth century until the 1930s in the case of the northern Balkan societies, and until the rise of military authoritarian regimes in the 1960s and 1970s for Greece and the southern cone countries - the latter's dictatorial regimes, as the Greek and Argentinian cases suggest, not necessarily entailing the irreversible demise of parliamentary democracy.

On the economic level, despite their relatively late start and their failure to industrialise in the last century, Greece, the northern Balkan and the southern Latin American countries all managed, through the development of their export sectors, first to build up a significant economic infrastructure, and then to achieve a rather impressive degree of industrialisation during the inter-war and post-war years.

This group of societies might be accurately characterised as 'late-late' industrialising capitalist societies ${ }^{4}$ with early and persistent quasi-parliamentary politics. Since this is a rather cumbersome label, the term parliamentary semi-periphery, or simply semiperiphery, will be used here. I am fully aware of the difficulties inherent in the centre-periphery terminology, especially as these concepts have been applied in the tradition of writings following Gunder Frank's and Emmanuel Wallerstein's theories. ${ }^{5}$ Given however that none of the concepts pertaining to the so-called third-world capitalist societies (that is, developing, underdeveloped, dependent, backward, and so on) are free of such difficulties, I have opted for the centre-periphery terminology with the proviso that my use of it is not taken to imply acceptance of Frank's or Wallerstein's views on capitalist development and on the specific mechanisms which, on the world-economy level, create centres, peripheries, and semi-peripheries. ${ }^{6}$ Neither is the label of parliamentary semi-periphery meant to imply an alternative theory of development/underdevelopment, or to operate as an exclusive category referring to a specific set of societies strictly different from the rest of the third world. (In fact, some of the generalisations formulated here are not without relevance to other societies which are either less industrialised or which have adopted parliamentary-democratic forms of rule somewhat later.)

In brief, the term parliamentary semi-periphery carries neither 
any great theoretical pretensions, nor is it the product of a complex and rigorous typology; it is simply being used here as a kind of shorthand, as a convenient term for referring to a number of societies all of which, unlike most other third-world countries, have experienced both advanced industrialisation and a long history of parliamentary-democratic rule. This combination of early and persistent parliamentarism and late industrialisation makes these countries quite comparable to western European societies. In view of this, certain economic and political patterns in the parliamentary semi-periphery are more or less explicitly compared in several parts of the book with those of the centre at similar stages of development. I realise of course the dangers of oversimplification and overgeneralisation entailed in such a comparative perspective of centre $v$. semi-periphery. Nevertheless, I hope to show that, despite these difficulties, adopting a broad, historically-oriented perspective does help towards a better understanding of the actual socio-political developments experienced by these countries. A similar though less systematic effort has been made to show some of the differences between the semi-periphery and the more peripheral capitalist societies.

Having clarified my use of the term parliamentary semiperiphery, it remains to outline the chief concerns of this book. Its major purpose is to show the fruitfulness of a Balkan-Latin American comparison by exploring the complex ways in which long-term, broad changes in the economy and society can help us explain certain crucial political transitions which occurred at approximately the same time in the countries under consideration.

The patrimonial type of rule experienced during their preindependence period by both Balkan and southern Latin American societies was hostile to the autonomous consolidation of corps intermédiaires between the ruler and the ruled. Despite significant differences in patterns of landownership for instance, in terms of state-civil society relationships neither Ottoman nor Iberian rule was prepared to tolerate any political autonomy of merchants or aristocrats vis-à-vis the central authority of the ruler. Whatever associations or collective bodies did represent, non-state interests were despotically controlled from above - at least when the ruler was strong (and so were the various officials manning the highly particularistic state apparatuses ${ }^{7}$ ). This situation is of course in sharp contrast to the subtle and, for some historians, unique 
balance of power between the ruler and the aristocracy (and later the bourgeoisie) in western European absolutism. ${ }^{8}$

The authoritarian/despotic features of the patrimonial state in the Balkans and southern Latin America did not disappear once these countries had acquired their political independence - not even when they adopted western parliamentary institutions during the second half of the nineteenth century. Indeed, the nineteenthcentury parliamentary regimes in the semi-periphery were based on very restricted popular participation, and on an authoritarian particularistic state controlled by a handful of notable families such families being able to keep the parliamentary system functioning stably by manipulating the electorate through a variety of legal and illegal means. However, with the fuller integration of these semi-peripheral societies into the world economy, their restrictive parliamentary regimes began to weaken as processes of market, state and city expansion undermined traditional mechanisms of political control and generated new political forces which eventually challenged the oligarchic monopoly of state power.

Part I of the book explores the demise of oligarchic parliamentarism and the mode of transition to broader forms of political participation - a transition which in all the countries under consideration took place during the first three decades of the twentieth century. Three distinct forms of transition are identified: (i) urban populism (the southern Latin American pattern), (ii) peasant populism (the pattern in the northern Balkan societies), and (iii) the broadening of political participation through the extension/transformation of already existing political patronage networks (the Greek pattern).

One of the major arguments to be developed extensively in Part $I$ is that, despite the wide variations in the mode of transition, in all the semi-peripheral societies under study the demise of oligarchic parliamentarism occurred in a predominantly pre-industrial context, and consequently the opening-up of the political system was not marked, as in several western European countries, by the active participation of the industrial classes (particularly by massive and relatively autonomous working-class organisations). Instead, the new middle- and lower-class participants and their organisations were brought into the political arena in a more dependent/vertical manner, and this type of vertical political inclusion, which I call incorporative, did not eliminate the particu- 
laristic/personalistic features of parliamentary politics; neither did it manage to check the authoritarian/despotic tendencies of the state. Moreover, when in the period after the 1929 Depression industrial capitalism gained momentum in these countries, its timing and structure meant that it did not weaken but rather transformed and reinforced these authoritarian structures inherited from the pre-independence era.

Therefore, both the post-oligarchic broadening of political participation and the subsequent acceleration of the industrialisation process contributed, in different ways, to a polity with a highly unequal distribution of political power between rulers and ruled. This unequal distribution of power and the institutional structures associated with it constituted a negative legacy; it provided a very inadequate basis for dealing democratically with the staggering problems that post-war semi-peripheral societies had to face once their economies were becoming more industrialised and their politics more fully marked by high levels of mass participation.

In Part II of the book the focus is restricted to only three societies of the parliamentary semi-periphery (Greece, Argentina and Chile) in order to show in greater detail the precise relevance of the political arrangements set up in the early post-oligarchic period for understanding the advent of highly repressive military dictatorial regimes in the post-war years. In identifying the basic structures and long-term processes which can help to explain more adequately the post-war rise of military dictatorships in Argentina, Chile and Greece, I have attempted to show both the elements held in common by these three countries as well as the systematic variations in their socio-political trajectories.

As I hope will become clear, the aim of this work is not to neglect the fundamental and fairly obvious differences that exist between the societies under consideration by fitting them into a procrustean bed of structural similarities. The aim is rather to show that those features they have in common provide a basis for a systematic comparison and explanation of their differences. Given the book's broad scope and the number of cases involved (especially in Part I) there is no attempt to deal in strictly chronological fashion with the various phases of economic and political development from the nineteenth century onwards; neither are events in each of these countries analysed exhaustively and methodically. Instead, examples from individual countries are used selectively to 


\section{xviii General Introduction}

illustrate some more general trends. For instance, in discussing (in Chapter 1) peasant populism as a form of transition to postoligarchic politics, Bulgaria's peasant movement (as the most powerful and representative in the Balkan peninsula) is the only one discussed in some detail. The same is true about the analysis of urban populism, where I consider in detail only the Argentinian case. It is in this way that I have tried to resolve the methodological dilemma of extensive but superficial coverage versus a restrictive analysis in depth.

In other words, the present work is not a detailed history of economic and political developments in the parliamentary semiperiphery. It simply tries, by means of a broad and historicallyoriented comparative analysis to identify certain common patterns of development, as well as certain significant variations in the social structures of the societies involved. A greater awareness of these common patterns and variations is, I think, helpful for a better understanding of both the overall highly chequered trajectory of these countries' parliamentary institutions, and of the two critical turning points in this trajectory: the early-twentiethcentury demise of oligarchic parliamentarism that led to a significant broadening of political participation and to the establishment of different types of inclusionary political regimes; and the post-war rise of exclusionary military regimes that tried through systematic repression to keep the masses out of active politics.

As the List of Contents shows, both Part I and Part II have a theoretical chapter which tries to draw out some of the implications of the preceding empirical analysis for the relevant literature. So Chapter 2 (Part I) clarifies and develops theoretically the concepts of populism, clientelism and political incorporation in the light of the concrete analysis of modes of transition to postoligarchic politics discussed in Chapter 1. This theoretical elaboration is intended both as a contribution to the general debate on the nature of populism and clientelism, as well as to prepare the ground for the analysis of post-war political developments that follows. Chapter 4 (Part II) deals with certain crucial debates in the literature on military interventions generally, and on the post-war rise of military dictatorial regimes particularly. Given the book's constant endeavour to relate developments in the economy to those taking place in the polity, the same chapter also discusses the more general and abstract issues of economic reductionism in 
Marxist theory and their relevance for the study of the two types of political transition under consideration.

In sum, the book is intended as a modest contribution to two interrelated areas of study. These are:

1. The comparative, cross-regional analysis of political development in a number of countries which, in terms of both their capitalist industrialisation and their early adoption of parliamentary institutions, come quite close to the western bourgeois parliamentary democracies.

2. The more theoretical writings in political sociology that deal with such issues as the fragility of democratic parliamentary regimes in third-world countries, the post-war rise of bureaucratic-authoritarian military rule in several late industrialisers, as well as (on a more abstract level) the nature of populism and political clientelism, and the adequacy of certain paradigms (particularly the Marxist one) for the study of politics in peripheral and semi-peripheral capitalist societies.

This multiplicity of aims entails the risk, of course, of falling between two or more stools. I have tried to minimise this risk both by giving more weight to the empirically-oriented comparative chapters, and by linking these chapters as closely as possible to the theoretical discussions that follow them. In any case, the present work does not claim to offer any definite or final solutions to the empirical and theoretical issues it raises; it merely presents a number of tentative ideas which, I hope, may stimulate empirical research and advance the more abstract debates on some basic themes and concepts of political theory.

A final word concerning the format and general organisation of the book. As I have tried to make the more empirical essays (Chapters 1 and 3) fairly self-contained, a certain amount of repetition has been unavoidable. At the same time, so as to render the major themes and arguments as concise as possible, I have used the Notes and References extensively to develop certain secondary arguments and, more generally, to provide additional information both theoretical and empirical. Although a long Notes and References section is not popular with publishers nowadays, I strongly believe that the reader should be given the choice of different readings according to his or her interests and time available. 